\title{
Penerapan Model Pembelajaran Kooperatif Tipe Cooperative Integrated Reading And Composition (CIRC) dalam Upaya Meningkatkan Kemampuan Pemecahan Masalah Matematika Siswa
}

\author{
E N.Qodariah ${ }^{1, a)}$, Yayu Nurhayati Rahayu ${ }^{1}$, $\operatorname{Karso}^{1}$, dan Agus Hikmat \\ Syaf ${ }^{1}$ \\ ${ }^{1}$ Prodi Pendidikan Matematika, UIN Sunan Gunung Djati Bandung, \\ Jl. A.H. Nasution No. 105, Cibiru , Bandung 40614, Indonesia \\ a)E-mail: pmtk@uinsgd.ac.id
}

\begin{abstract}
Abstrak. Penelitian ini bertujuan untuk mengetahui bagaimana aktivitas guru dan siswa, bagaimana kemampuan pemecahan masalah siswa, dan bagaimana sikap siswa kelas VIIA MTs Al-Mufassir dengan model pembelajaran kooperatif tipe Cooperative Integrated Reading and Composition (CIRC) pada pembelajaran matematika pokok bahasan segi empat. Metode penelitian yang digunakan adalah Penelitian Tindakan Kelas (PTK) dengan langkahlangkah yang dilakukan berupa kegiatan siklus yaitu plan (perencanaan), act (tindakan), observe (pengamatan), dan reflect (refleksi). Sample dalam penelitian ini berjumlah 32 siswa yang memiliki kemampuan heterogen. Instrumen yang digunakan untuk mengumpulkan data dalam penelitian ini adalah instrument observasi untuk mengetahui aktivitas guru dan siswa, instrumen skala sikap untuk mengetahui sikap siswa dan tes untuk mengukur kemampuan pemecahan masalah matematika. Hasil penelitian dapat disimpulkan bahwa penerapan model pembelajaran kooperatif tipe CIRC sangat efektif untuk meningkatkan aspek kemampuan pemecahan masalah pada pokok bahasan segiempat. Disarankan dapat dimanfaatkan sebagai masukan atau bahan pertimbangan bagi guru khususnya pada mata pelajaran matematika bahwa pembelajaran kooperatif tipe CIRC perlu dikembangkan dan diterapkan karena pembelajaran tersebut dapat meningkatkan aspek kemampuan pemecahan masalah.
\end{abstract}

Kata Kunci. Cooperative Integrated Reading and Compotition, Pemecahan Masalah Matematika Siswa

\section{Pendahuluan}

Matematika memiliki peranan penting dalam berbagai aspek kehidupan. Adapun pengertian matematika sangat sulit didefinsikan secara akurat. Menurut Jonson dan Rising (1972), Matematika dikatakan sebagai pengetahuan struktur yang terorganisasi, sifat-sifat atau teori dibuat secara deduktif berdasarkan pada unsur yang didefinisikan, aksioma, teori yang telah dibuktikan kebenarannya (Priyanto, 2009). Banyak permasalahan dan kegiatan dalam kehidupan kita yang harus diselesaikan dengan menggunakan ilmu matematika seperti menghitung, mengukur, dan lain-lain. Dengan mempelajari matematika siswa selalu dihadapkan kepada masalah matematika yang terstruktur, sistematis dan logis yang dapat membiasakan siswa untuk mengatasi 
masalah yang timbul secara mandiri dalam kehidupannya tanpa harus selalu meminta bantuan kepada orang lain.

Pada penelitian ini penilaian lebih ditekankan hanya untuk mengukur kemampuan pemecahan masalah. Polya mendefinisikan bahwa pemecahan masalah merupakan suatu usaha mencari jalan keluar dari suatu kesulitan guna mencapai suatu tujuan yang tidak begitu mudah segera dapat dicapai (susilawati, 2008:111).

Penulis menyimpulkan bahwa kemampuan pemecahan masalah adalah kesanggupan siswa untuk mencari metode penyelesaian dan memikirkan solusi-solusi alternatif dari suatu masalah yang diberikan. Adapun suatu soal/pertanyaan akan merupakan suatu masalah hanya jika siswa tidak mempunyai aturan/hukum tertentu yang segera dapat dipergunakan untuk menemukan jawaban pertanyaan tersebut atau dengan kata lain suatu pertanyaan akan menjadi masalah hanya jika pertanyaan itu menunjukan suatu tantangan yang tidak dapat dipecahkan oleh suatu prosedur rutin yang sudah diketahui.

Indikasi pemecahan masalah dalam pembelajaran matematika adalah agar siswa mampu memecahkan masalah yang dihadapi dalam kehidupannya. Bentuk soal pemecahan masalah yang difokuskan pada penelitian ini adalah soal cerita. Soal cerita dalam kehidupan sehari-hari lebih ditekankan kepada penajaman intelektual anak sesuai dengan kenyataan yang mereka hadapi. Namun kenyataannya banyak siswa yang mengalami kesulitan dalam memahami arti kalimat-kalimat dalam soal cerita, kurang mampu memisalkan apa yang diketahui dan apa yang ditanyakan, kurang bisa menghubungkan secara fungsional unsur-unsur yang diketahui untuk menyelesaikan masalahnya, dan unsur mana yang harus dimisalkan dengan suatu variabel.

Oleh karena itu, perlu upaya untuk meningkatkan hasil belajar siswa yaitu dengan melakukan penelitian tindakan kelas dan memberlakukan pembelajaran yang efektif untuk memperbaiki keadaan. Salah satu model pembelajaran yang efektif dan menarik adalah pembelajaran kooperatif dimana siswa belajar bersama dalam kelompok-kelompok kecil yang bekerja untuk menyelesaikan suatu masalah, menyelesaikan suatu tugas atau mengerjakan sesuatu untuk mencapai tujuan bersama.

Ada banyak model pembelajaran cooperative learning dalam pembelajaran matematika yang memenuhi ciri pembelajaran efektif salah satunya adalah model Cooperative Integrated Reading and Composition (CIRC). CIRC termasuk 
Penerapan Model Pembelajaran Kooperatif Tipe Cooperative Integrated Reading And Composition (CIRC) dalam Upaya Meningkatkan Kemampuan Pemecahan Masalah Matematika Siswa

salah satu model pembelajaran cooperative learning. Model pembelajaran kooperatif (cooperative learning) adalah suatu model pembelajaran dimana siswa belajar dalam kelompok-kelompok kecil yang memiliki tingkat kemampuan berbeda (Widyaningsih W, dkk, 2008:9). Adapun ciri dari pembelajaran kooperatif yang dikemukakan oleh (Widyaningsih W, dkk, 2008:12) diantaranya; (a) Siswa bekerja dalam kelompok secara kooperatif untuk menuntaskan materi belajarnya. (b) Kelompok dibentuk dari siswa yang memiliki kemampuan tinggi, sedang, dan rendah. (c) Bilamana mungkin, anggota kelompok berasal dari ras, bangsa, suku, dan jenis kelamin yang berbeda-beda. (d) Penghargaan lebih berorientasi kepada kelompok daripada individu.

CIRC dapat membantu siswa untuk mengasah kemampuan pemecahan masalah dalam menyelesaikan soal cerita. Sehingga dengan model pembelajaran tersebut siswa mampu dan terampil menyelesaikan masalah dalam soal cerita dengan langkahlangkah yang tepat.

Penelitian yang dilakukan mengambil sub pokok bahasan penerapan bangun segiempat, karena dalam kehidupan seharihari sering dijumpai kejadian yang Jurnal Analisa Vol 1 No.1 Juni 2013 :41-49 berhubungan dengan materi tersebut, misalnya untuk menentukan luas atau keliling suatu tanah dan bangunan, menghitung besarnya uang yang dikeluarkan untuk membeli suatu tanah dan disamping itu banyak sekali soal cerita yang disajikan dalam latihan pada pokok bahasan segiempat.

Berdasarkan uraian di atas, penulis berasumsi bahwa pembelajaran yang tepat untuk meningkatkan kemampuan pemecahan masalah dalam pokok bahasan segiempat adalah dengan pembelajaran CIRC. Oleh karena itu, peneliti merasa tertarik untuk melakukan penelitian dengan tujuan untuk mengetahui bagaimana aktivitas guru dan siswa, bagaimana kemampuan pemecahan masalah siswa, dan bagaimana sikap siswa kelas VIIA MTs Al-Mufassir dengan model pembelajaran kooperatif tipe Cooperative Integrated Reading and Composition (CIRC) pada pembelajaran matematika pokok bahasan segi empat. Sehingga dapat dimanfaatkan sebagai masukan atau bahan pertimbangan bagi guru khususnya pada mata pelajaran matematika bahwa pembelajaran kooperatif tipe CIRC perlu dikembangkan dan diterapkan karena 
pembelajaran tersebut dapat meningkatkan aspek kemampuan pemecahan masalah.

\section{Metodologi Penelitian}

Penelitian ini dilakukan di MTs AlMufassir kec. Paseh kab. Bandung, dikarenakan penulis melihat kegiatan proses belajar mengajar yang dilaksanakan di MTs. Al- Mufassir masih sederhana dalam arti guru jarang mencoba modelmodel pembelajaraan baru. Metode yang dilakukan dalam penelitian ini adalah Penelitian Tindakan Kelas (PTK) dengan langkah-langkah yang dilakukan berupa kegiatan siklus yaitu plan (perencanaan), act (tindakan), observe (pengamatan), dan reflect (refleksi). Instrumen yang digunakan untuk mengumpulkan data dalam penelitian ini adalah instrument observasi untuk mengetahui aktivitas guru dan siswa yang dilakukan oleh observer, instrumen skala sikap untuk mengetahui sikap siswa menggunakan skala likert dan instrumen tes untuk mengukur kemampuan pemecahan masalah matematika. Adapun tes yang digunakan dalam penelitian ini adalah jenis tes uraian yang meliputi tes evaluasi siklus dan posttest, hal ini dimaksudkan agar dapat terlihat kemampuan pemecahan masalah pada diri siswa sebenarnya.

\section{Hasil dan Pembahasan}

Berdasarkan penelitian yang telah dilakukan di MTs. Al- Mufassir diperoleh hasil penelitian sebagai berikut:

Berdasarkan hasil analisis observasi diperoleh bahwa perkembangan aktivitas siswa mengalami peningkatan, hal ini dapat dilihat dari rata-rata persentase aktivitas siswa pada tiap pertemuan. Dari siklus I $(66,54 \%)$ ke siklus II $(75,39 \%)$ kemudian siklus III (82,23\%). aktivitas siswa mengalami peningkatan sebesar $15.69 \%$. Kondisi ini menggambarkan bahwa siswa merasa senang dan mampu mengikuti kegiatan proses pembelajaran yang diterapkan oleh guru. Secara keseluruhan rata-rata persentase aktivitas siswa pada setiap pembelajaran disajikan pada Tabel 1 dan Gambar 1.

Table 1 Rata-Rata Persentase Aktivitas

Siswa Pada Tiap Siklus

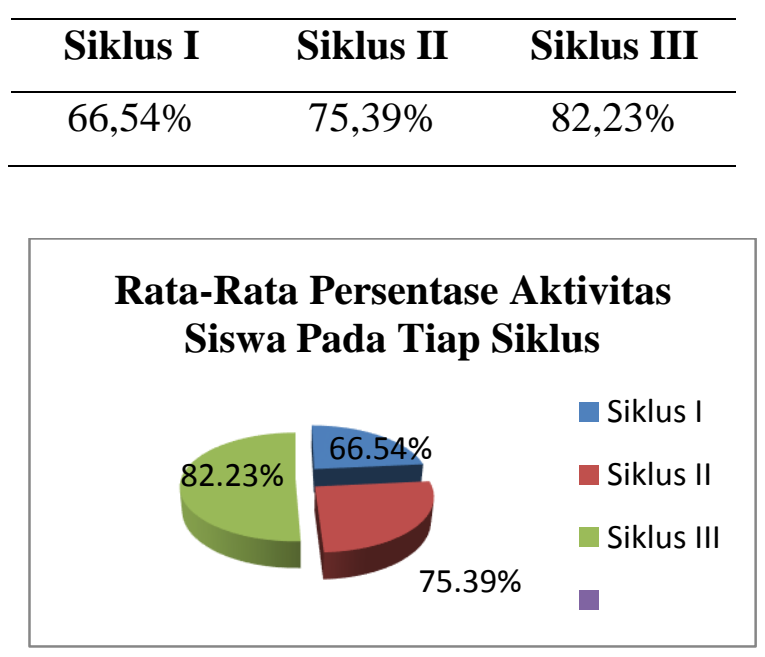

Gambar 1 Grafik Peningkatan Aktivitas Siswa pada Tiap Pertemuan 
Penerapan Model Pembelajaran Kooperatif Tipe Cooperative Integrated Reading And Composition (CIRC) dalam Upaya Meningkatkan Kemampuan Pemecahan Masalah Matematika Siswa

Berdasarkan hasil analisis skala sikap diketahui bahwa tanggapan siswa terhadap pembelajaran matematika dengan menggunakan pembelajaran CIRC sangat baik.

Persentase Sikap Positif Siswa Terhadap Pembelajaran Matematika Model CIRC

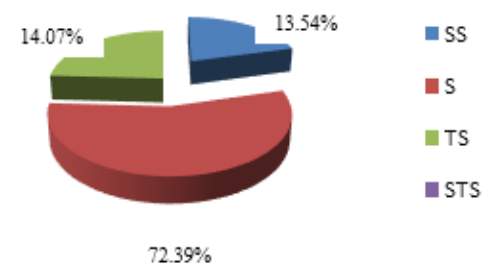

Gambar 2 Diagram Presentase Sikap Positif Siswa Terhadap Pembelajaran Model CIRC

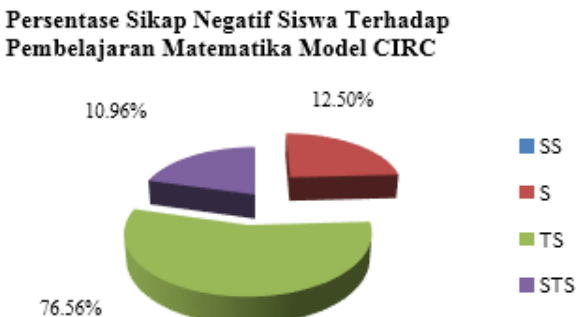

Gambar 3 Diagram Presentase Sikap

Negatif Siswa Terhadap Pembelajaran

\section{Model CIRC}

Dari gambar 2 dan 3 dapat dijelaskan siswa yang memiliki sikap positif terhadap pembelajaran CIRC menyatakan setuju dan sangat setuju sebesar $85.93 \%$ dan sikap Jurnal Analisa Vol 1 No.1 Juni 2013 :41-49 negatif terhadap pembelajaran CIRC dengan menyatakan tidak setuju dan sangat tidak setuju sebesar $87.52 \%$ dari 32 siswa.

Adapun tanggapan siswa terhadap soalsoal pemecahan masalah matematika yang diberikan guru menuntut kemampuan pemecahan masalah matematik siswa baik. Untuk lebih jelasnya tentang tanggapan positif siswa terhadap soal-soal pemecahan masalah matematika dengan menggunakan pembelajaran CIRC, perhatikan gambar 4 .

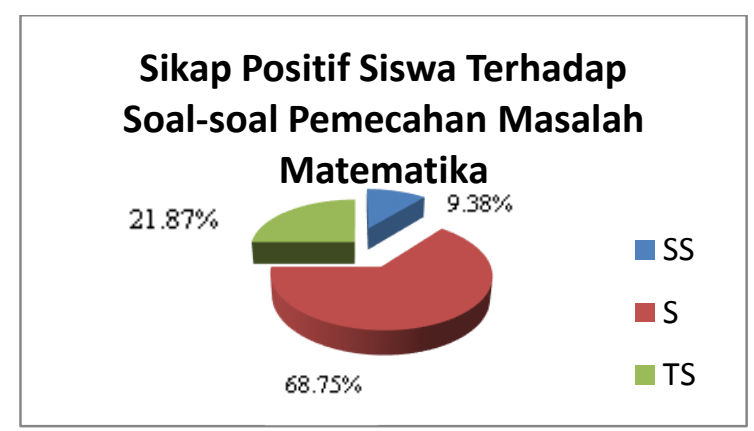

Gambar 4 Diagram Presentase Sikap Positif Siswa Terhadap Soal Pemahaman 


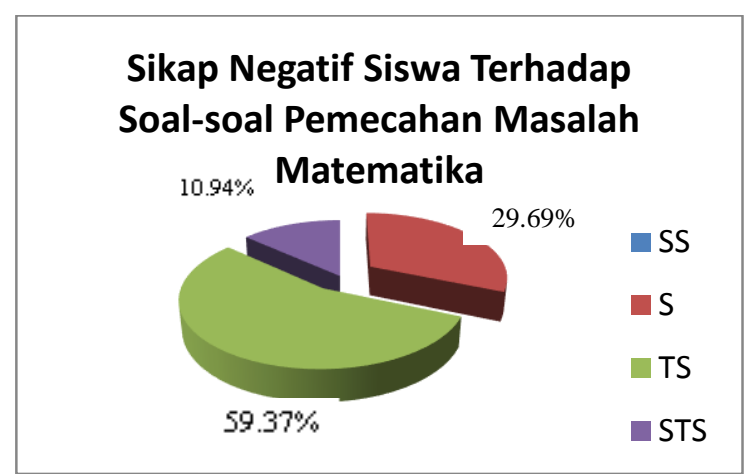

Gambar 5 Diagram Presentase Sikap

Negatif Siswa Terhadap Soal Pemahaman

Dari gambar 4 dapat diinformasikan siswa yang memiliki sikap positif terhadap soalsoal pemahaman matematika dengan menyatakan setuju dan sangat setuju sebesar $78.13 \%$ artinya siswa sangat setuju dan senang dengan soal-soal pemecahan masalah matematika, dan sikap negatif siswa pada gambar 5 terhadap soal-soal pemecahan masalah matematika dengan menyatakan tidak setuju dan sangat tidak setuju adalah $70.31 \%$ dari 32 siswa.

Selanjutnya tentang tanggapan positif siswa terhadap faktor-faktor yang mempengaruhi kemampuan pemecahan masalah matematika siswa dengan menggunakan pembelajaran CIRC, perhatikan gambar 6 berikut.

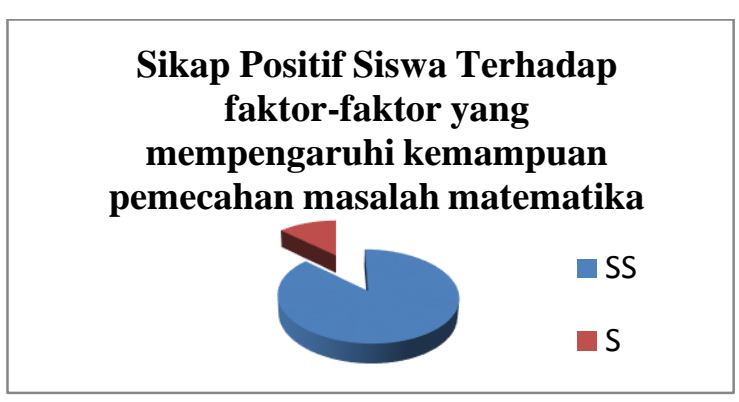

Gambar 6 Diagram Presentase Sikap Positif Siswa Terhadap Faktor-faktor yang Mempengaruhi Kemampuan Pemecahan

Masalah Matematika

Berdasarkan hasil analisis data skala sikap, diperoleh bahwa sikap siswa terhadap pembelajaran CIRC dan terhadap soal-soal pemecahan masalah matematika juga terhadap faktor-faktor yang mempengaruhi kemampuan pemecahan masalah matematika siswa baik. Sehingga dapat disimpulkan bahwa siswa merasa senang mengikuti pembelajaran matematika dengan pembelajaran CIRC dan tertarik untuk memahami dan menyelesaikan permasalahan matematik yang berhubungan dengan masalah sehari-hari.

Setelah seluruh siklus pembelajaran selesai, maka siswa diberikan tes akhir dengan tujuan untuk mengetahui kemampuan pemecahan masalah matematika siswa pada materi Keliling dan Luas Bangun Datar setelah mengikuti pembelajaran dengan model kooperatif tipe CIRC. Berikut ini disajikan rekapitulasi hasil tes tiap indikator pada tabel 2 . 
Penerapan Model Pembelajaran Kooperatif Tipe Cooperative Integrated Reading And Composition (CIRC) dalam Upaya Meningkatkan Kemampuan Pemecahan Masalah Matematika Siswa

beberapa prosedur yang benar dan

Berdasarkan perhitungan dari post test dapat diketahui bahwa siswa yang dapat mengerjakan soal $\geq 65 \%$ sebanyak 32 siswa dari 32. Hal ini berarti menggambarkan bahwa tes akhir dari siswa kelas VII-A pada pembelajaran materi keliling dan luas bangun datar dengan pembelajaran menggunakan model kooperatif tipe CIRC, dengan rata-rata nilai 75.78 memiliki kriteria tinggi. Sedangkan dari table 2 dapat diketahui bahwa untuk indikator mengidentifikasi unsur yang diketahui sekitar $65 \%$ siswa dapat memahami soal dengan baik, dan hanya sekitar $35 \%$ siswa menginterpretasi soal kurang tepat.

Untuk indikator merumuskan masalah sekitar $59.38 \%$ siswa menggunakan beberapa strategi yang benar dan mengarah pada jawaban yang benar, dan sekitar $23.75 \%$ siswa kelas VII-A menggunakan suatu strategi tertentu tetapi mengarah pada jawaban yang salah, dan $16.87 \%$ siswa yang menggunakan satu strategi tertentu tapi tidak dilanjutkan, dan tidak ada siswa yang menggunakan strategi yang kurang relevan. Kemudian untuk indikator menerapkan strategi penyelesaian masalah, ada $31.25 \%$ siswa menggunakan Jurnal Analisa Vol 1 No.1 Juni 2013 :41-49 mengarah pada jawaban yang benar, dan sekitar $23.75 \%$ siswa kelas VII-A menggunakan prosedur yang benar tetapi salah dalam menghitung, dan $41.25 \%$ menggunakan satu prosedur tertentu yang mengarah pada jawaban yang benar dan sisanya $3.75 \%$ ada penyelesaian tapi prosedur tidak jelas.

Dan terakhir untuk indikator Menginterpretasikan hasil sekitar $13.75 \%$ siswa melakukan pengecekan hanya pada jawaban, dan $36.25 \%$ siswa melakukan pengecekan hanya pada prosesnya, dan $50 \%$ siswa yang melakukan pengecekan terhadap proses dan jawabannya. 
Table 2 Rekapitulasi Hasil Tes Tiap Indikator

\begin{tabular}{|c|c|c|c|c|c|c|c|}
\hline \multirow{2}{*}{ No } & \multirow{2}{*}{ Indikator } & \multirow{2}{*}{$\begin{array}{c}\text { No } \\
\text { soal }\end{array}$} & \multicolumn{4}{|c|}{ Skor/Level } & \multirow{2}{*}{ Jmlh } \\
\hline & & & 1 & 2 & 3 & 4 & \\
\hline \multirow{12}{*}{1} & \multirow{10}{*}{$\begin{array}{l}\text { Mengidentifikasi } \\
\text { unsur yang di } \\
\text { ketahui }\end{array}$} & 1 & 11 & 21 & - & - & 32 \\
\hline & & & $34.37 \%$ & $65.63 \%$ & 0 & 0 & $100 \%$ \\
\hline & & 2 & 5 & 27 & - & - & 32 \\
\hline & & & $15.62 \%$ & $84.38 \%$ & 0 & 0 & $100 \%$ \\
\hline & & 3 & 11 & 21 & - & - & 32 \\
\hline & & & $34.37 \%$ & $65.63 \%$ & 0 & 0 & $100 \%$ \\
\hline & & 4 & - & 32 & - & - & 32 \\
\hline & & & 0 & $100 \%$ & 0 & 0 & $100 \%$ \\
\hline & & 5 & 29 & 3 & - & - & 32 \\
\hline & & & $90.62 \%$ & $9.38 \%$ & 0 & 0 & $100 \%$ \\
\hline & Rata-Rata & & 11.2 & 20.8 & & & 32 \\
\hline & Persentase & & $35 \%$ & $65 \%$ & & & $100 \%$ \\
\hline \multirow{12}{*}{2} & \multirow{10}{*}{$\begin{array}{l}\text { Merumuskan } \\
\text { masalah }\end{array}$} & 1 & - & 6 & 8 & 18 & 32 \\
\hline & & & 0 & $18.75 \%$ & $25 \%$ & $56.25 \%$ & $100 \%$ \\
\hline & & 2 & - & 1 & 8 & 23 & 32 \\
\hline & & & 0 & $3.13 \%$ & $25 \%$ & $71.87 \%$ & $100 \%$ \\
\hline & & 3 & - & 7 & 5 & 20 & 32 \\
\hline & & & 0 & $21.87 \%$ & $15.63 \%$ & $62.5 \%$ & $100 \%$ \\
\hline & & 4 & - & - & - & 32 & 32 \\
\hline & & & 0 & 0 & 0 & $100 \%$ & $100 \%$ \\
\hline & & 5 & - & 13 & 17 & 2 & 32 \\
\hline & & & 0 & $40.62 \%$ & $53.13 \%$ & $6.25 \%$ & $100 \%$ \\
\hline & Rata-Rata & & 0 & 5.4 & 7.6 & 19 & 32 \\
\hline & Persentase & & 0 & $16.87 \%$ & $23.75 \%$ & $59.38 \%$ & $100 \%$ \\
\hline \multirow{12}{*}{3} & \multirow{10}{*}{$\begin{array}{l}\text { Menerapkan } \\
\text { strategi } \\
\text { penyelesaian } \\
\text { masalah }\end{array}$} & 1 & 3 & 15 & 11 & 3 & 32 \\
\hline & & & $9.38 \%$ & $46.875 \%$ & $34.37 \%$ & $9.38 \%$ & $100 \%$ \\
\hline & & 2 & - & 13 & 11 & 8 & 32 \\
\hline & & & 0 & $40.63 \%$ & $34.37 \%$ & $25 \%$ & $100 \%$ \\
\hline & & 3 & 3 & 12 & 12 & 5 & 32 \\
\hline & & & $9.38 \%$ & $37.5 \%$ & $37.5 \%$ & $15.62 \%$ & $100 \%$ \\
\hline & & 4 & - & - & - & 32 & 32 \\
\hline & & & 0 & 0 & 0 & $100 \%$ & $100 \%$ \\
\hline & & 5 & - & 26 & 4 & 2 & 32 \\
\hline & & & 0 & $81.25 \%$ & $12.5 \%$ & $6.25 \%$ & $100 \%$ \\
\hline & Rata-Rata & & 1.2 & 13.2 & 7.6 & 10 & 32 \\
\hline & Persentase & & $3.75 \%$ & $41.25 \%$ & $23.75 \%$ & $31.25 \%$ & $100 \%$ \\
\hline \multirow{12}{*}{4} & \multirow{10}{*}{$\begin{array}{l}\text { Menginterpretasik } \\
\text { an hasil }\end{array}$} & 1 & - & 21 & 11 & - & 32 \\
\hline & & & 0 & $65.63 \%$ & $34.37 \%$ & 0 & $100 \%$ \\
\hline & & 2 & - & 16 & 16 & - & 32 \\
\hline & & & 0 & $50 \%$ & $50 \%$ & 0 & $100 \%$ \\
\hline & & 3 & - & 18 & 14 & - & 32 \\
\hline & & & 0 & $56.25 \%$ & $43.75 \%$ & 0 & $100 \%$ \\
\hline & & 4 & - & - & 32 & - & 32 \\
\hline & & & 0 & 0 & $100 \%$ & 0 & $100 \%$ \\
\hline & & 5 & 22 & 3 & 7 & - & 32 \\
\hline & & & 68.75 & $9.375 \%$ & $21.875 \%$ & 0 & $100 \%$ \\
\hline & Rata-Rata & & 4.4 & 11.6 & 16 & 0 & \\
\hline & Persentase & & $13.75 \%$ & $36.25 \%$ & $50 \%$ & - & \\
\hline
\end{tabular}


Adapun kriteria penilaian kemampuan pemecahan masalah matematika siswa pada post test dapat dilihat pada table 3 di bawah ini.

Table 3 Klasifikasi Kualitas Kemampuan Pemecahan Masalah

\begin{tabular}{ccl}
\hline Rentang Nilai & Jumlah Siswa & \multicolumn{1}{c}{ Klasifikasi } \\
\hline $90 \% \leq \mathrm{A} \leq 100 \%$ & 2 & Sangat Tinggi \\
$75 \% \leq \mathrm{B}<90 \%$ & 18 & Tinggi \\
$55 \% \leq \mathrm{C}<75 \%$ & 12 & Cukup \\
$40 \% \leq \mathrm{D}<55 \%$ & 0 & Rendah \\
$00 \% \leq \mathrm{E}<40 \%$ & 0 & Sangat Rendah \\
\hline
\end{tabular}

\section{Simpulan dan Saran}

Berdasarkan hasil perhitungan serta analisis penelitian yang sudah dipaparkan sebelumnya, maka dapat disimpulkan: (1) aktivitas siswa mengalami peningkatan pada tiap siklusnya. Sedangkan aktivitas guru selama proses pembelajaran selalu berpijak pada tahap-tahap pembelajaran yang telah direncanakan. (2) kemampuan pemecahan masalah matematik siswa setelah diterapkan model pembelajaran Kooperatif tipe CIRC menunjukkan pada kriteria tinggi. (3) sikap siswa terhadap pembelajaran matematika melalui penerapan model pembelajaran CIRC cukup baik. Untuk itu guru diharapkan didalam pembelajaran Matematika dengan menggunakan pembelajaran Kooperatif ini untuk lebih kreatif mengajak siswa secara pro aktif sehingga siswa mempunyai konsep yang tinggi dalam memecahkan permasalahan yang muncul dalam memahami pokok bahasan Segi Empat ini.

\section{Daftar Pustaka}

Priyanto, 2009. Hakikat Pendidikan Matematika. http://www.ajipriyanto.co.cc/2009/02/ha kikat-pendidikan-matematika.html

Susilawati, Wati. 2008. Belajar dan Pembelajaran Matematika.

Widyaningsih W, dkk, 2008: Cooperative Learning Sebagai Model Pembelajaran Alternatif untuk Meningkatkan Motivasi Belajar Siswa http://luarsekolah.blogspot.com 